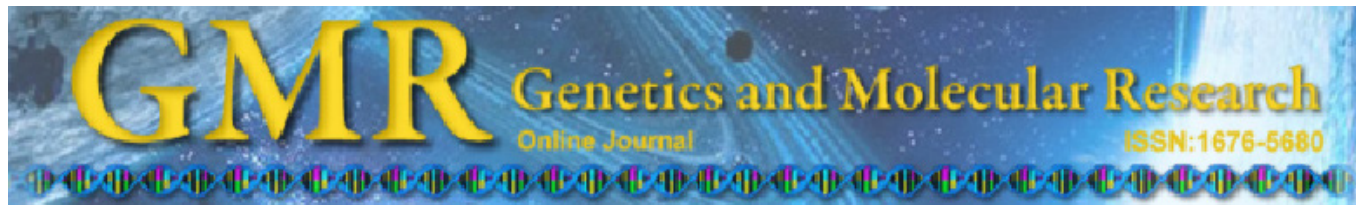

\title{
Cellular responses induced in vitro by iron (Fe) in a central nervous system cell line (U343MGa)
}

D.D.F.A. Alcântara, H.F. Ribeiro, L.A. Matos, J.M.C. Sousa, R.R. Burbano and M.O. Bahia

Laboratório de Citogenética Humana, Instituto de Ciências Biológicas, Universidade Federal do Pará, Belém, PA, Brasil

Corresponding author: M.O. Bahia

E-mail:mbahia@ufpa.br

Genet. Mol. Res. 12 (2): 1554-1560 (2013)

Received May 16, 2012

Accepted November 29, 2012

Published May 13, 2013

DOI http://dx.doi.org/10.4238/2013.May.13.9

\begin{abstract}
Iron is the most important metallic chemical element on Earth. Poisoning caused by excessive iron in humans has been associated with pulmonary diseases including neoplasms caused by inhalation of iron oxides. The involvement of iron in neurodegenerative processes has already been described. DNA alterations are induced by iron and other chemical compounds containing this metal; however, the data are controversial and the mechanism by which iron induces mutagenesis remains unknown. This study assessed in vitro iron-induced cytotoxic and genotoxic responses in an astrocytic cell line. Short- and long-term cytotoxicity and genotoxicity were evaluated with the Cell Proliferation Kit II and micronucleus test, respectively. Results indicated that the highest concentration of iron sulfate tested was cytotoxic in long-term cytotoxic assays and increased micronucleus frequency in comparison to controls. The significant cytotoxicity observed here might be due to the intrinsic ability of iron to induce apoptosis and possible changes in cell cycle kinetics; the genotoxic effects are probably due to the oxidant properties of iron itself. This was the first study to investigate the induction of micronuclei by iron in central nervous system cells.
\end{abstract}

Key words: Central nervous system; Cytotoxicity; Iron; Micronuclei 


\section{INTRODUCTION}

Along with aluminum ( $\mathrm{Al})$, iron $(\mathrm{Fe})$ is the most important metallic chemical element on Earth (O’Neil, 1994). Poisoning caused by excessive Fe in humans has been associated with pulmonary diseases including neoplasms caused by inhalation of $\mathrm{Fe}$ oxides (Chau et al., 1993), as well as heart and liver diseases, diabetes, and hormonal and immunological dysfunction (Salonen et al., 1992; Gardi et al., 2002; Trinder et al., 2002). The involvement of iron in neurodegenerative processes such as Alzheimer's and Parkinson's disease (AD and PD, respectively) has been described (Smith et al., 1997; Fasano et al., 2003). In this context, Fe oxidation induced by the Fenton reaction could lead to protein aggregation, free radical induction, and oxidative stress, common features of neurodegenerative disturbances. Interaction between $\mathrm{Fe}$ and proteins seems to be a crucial factor in the development or absence of neurodegenerative disorders (Rivera-Mancía et al., 2010).

There have been many reports of DNA alterations induced by Fe and other chemical compounds containing this metal. However, the results have been controversial and the mechanism by which Fe induces mutagenicity remains unclear (Heidelberger et al., 1983; Abalea et al., 1999). Dunkel et al. (1999) showed that iron sulfate was the least efficient iron derivate able to induce mutations in Salmonella typhimurium. Anderson et al. (2000a) reported that ferric chloride produces high levels of DNA damage in human colon cells, but little or no damage in human lymphocytes. Ferric chloride also induces little damage in human lymphocytes, while treatment with ferrous sulfate induces a dose-dependent DNA damage (Anderson et al., 2000b).

Although Fe contamination is associated with kidney cancer (Linehan et al., 2010) and neurodegenerative diseases, studies evaluating genotoxicity in central nervous system (CNS) cells are scarce (Alexandrov et al., 2005; Lukiw and Pogue, 2007). Therefore, the aim of this study was to assess in vitro cytotoxic and genotoxic responses induced by $\mathrm{Fe}$ in an astrocytic cell line (U343 MG-a). To our knowledge, this was the first study to investigate the induction of micronuclei in binucleated U343 MG-a cells.

\section{MATERIAL AND METHODS}

\section{Chemical compounds}

Iron sulfate heptahydrate $\left(\mathrm{FeSO}_{4} \cdot 7 \mathrm{H}_{2} \mathrm{O}\right.$, CAS No. 7782-63-0) and doxorubicin (CAS No. 23214-92-8) were purchased from Sigma Chemical Co., USA, and diluted in distilled water. Stock solutions were stored at $-20^{\circ} \mathrm{C}$.

\section{Cell culture}

Astrocytic cell line U343 MG-a was established from a primary adult astrocytoma resection; it is p16-deficient and p53-positive (Hiyama and Reeves, 1999) and was kindly supplied by Dr. Carlos Gilberto Carlotti Jr (FMRP-USP) and Dr. Elza Tiemi Sakamoto-Hojo (FMRP-USP). Cells were grown in 1:1 (v/v) HAM F10 + DMEM (Sigma Chemical Co.) supplemented with $15 \%$ fetal bovine serum (Gibco, USA), $0.1 \mathrm{mg} / \mathrm{mL}$ kanamycin, $0.02 \mathrm{mg} /$ $\mathrm{mL}$ ciprofloxacin, $0.1 \mathrm{mg} / \mathrm{mL}$ streptomycin, and $99 \mathrm{U} / \mathrm{mL}$ penicillin and kept in an incubator at $37^{\circ} \mathrm{C}$. Cells were subcultured 2 or 3 times a week. 


\section{Cytotoxicity and cell survival}

The Cell Proliferation Kit II (XTT), a colorimetric XTT assay (Roche), was used to evaluate cytotoxicity and cell survival. For cytotoxicity tests, $5 \times 10^{4}$ cells were seeded per well on 96-well tissue culture plates. Iron sulfate $(10,20,40,80,160,320$, and $640 \mu \mathrm{g} / \mathrm{mL})$ was added to each well and incubated for $24 \mathrm{~h}$. A negative control containing only culture medium was also assessed. Twenty-four hours after the end of treatment, XTT was added for $3 \mathrm{~h}$, according to the manufacturer protocol. Absorbance at $562 \mathrm{~nm}$ was measured by a spectrophotometer (Eppendorf Biophotometer). Cell survival was expressed as a percentage of untreated cells, the negative control group designated $100 \%$. All assays were performed in triplicate. The procedure for cell survival was the same, with $0.5 \times 10^{4}$ cells and XTT addition $96 \mathrm{~h}$ after the end of treatment.

\section{Micronucleus test}

U343 cells were treated with iron for $24 \mathrm{~h}$. After treatment, $3 \mu \mathrm{g} / \mathrm{mL}$ cytochalasin B (Sigma Chemical Co.) was added for another $24 \mathrm{~h}$ at $37^{\circ} \mathrm{C}$. Cells were harvested, centrifuged for $5 \mathrm{~min}$ at $800 \mathrm{rpm}$ and treated with $3 \mathrm{~mL}$ hypotonic solution (1\% sodium citrate) plus 2

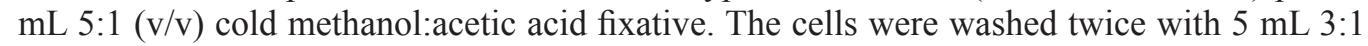
$(\mathrm{v} / \mathrm{v})$ cold methanol:acetic acid solution. Slides were prepared and stained in a solution of 5\% Giemsa dye (Sigma Chemical Co.) in phosphate buffer, $\mathrm{pH}$ 6.8, for 5 min. Micronuclei (MN) were scored in 1000 binucleated cells using criteria described elsewhere (Fenech et al., 2003). The frequency of binucleated cells containing one or more MN was also determined. As a measure of cytotoxicity, the cytokinesis-block proliferating index (CBPI) was calculated according to the following formula: $\mathrm{CBPI}=[\mathrm{M} 1+2(\mathrm{M} 2)+3(\mathrm{M} 3)+4(\mathrm{M} 4)] / \mathrm{N}$, where $M 1$ M4 represents the number of cells with 1-4 nuclei per 500 cells. Iron concentrations were 40 , 160 , and $640 \mu \mathrm{g} / \mathrm{mL}$. As a positive control, doxorubicin was used at a final concentration of $0.0173 \mu \mathrm{g} / \mathrm{mL}$.

\section{Statistical analyses}

Results are reported as means $\pm \mathrm{SD}$ for 3 independent experiments $(\mathrm{N}=3)$. Multiple variance analysis (ANOVA) and the post hoc Tukey test were performed. We also used a non-parametric test (Kruskal-Wallis). A value of $\mathrm{P}<0.05$ was considered to be statistically significant for all parameters. Analyses were performed in BioEstat 5.0 (Ayres et al., 2007).

\section{RESULTS}

XTT results showed a reduction in cell survival at $\geq 40 \mu \mathrm{g} / \mathrm{mL}$ iron sulfate; however, the reduction was statistically significant $(\mathrm{P}<0.05)$ only at $640 \mu \mathrm{g} / \mathrm{mL}$. However, cytotoxicity $24 \mathrm{~h}$ after treatment was not statistically different. Table 1 shows the mean values obtained for cytotoxicity and cell survival at each concentration, in addition to the optical density values obtained by spectrophotometry. For the MN test, the only concentrations that produced over $50 \%$ cell survival (based on XTT assay results) were used. 
Table 1. Cytotoxicity, cell survival and optical density values observed in the U343 cell line after exposition to different concentrations of $\mathrm{FeSO}_{4} \cdot 7 \mathrm{H}_{2} \mathrm{O}$.

\begin{tabular}{lcccc}
\hline $\mathrm{FeSO}_{4} \cdot 7 \mathrm{H}_{2} \mathrm{O}(\mu \mathrm{g} / \mathrm{mL})$ & Cytotoxicity $(\%)$ & Cytotoxicity optical density $( \pm \mathrm{SD})$ & Cell survival $(\%)$ & Cell survival optical density $( \pm \mathrm{SD})$ \\
\hline Control & 100.0 & $1.00( \pm 0.07)$ & 100.0 & $0.93( \pm 0.09)$ \\
10 & 96.9 & $0.97( \pm 0.17)$ & 99.2 & $0.92( \pm 0.05)$ \\
20 & 100.7 & $1.00( \pm 0.07)$ & 100.0 & $0.94( \pm 0.12)$ \\
40 & 99.0 & $0.99( \pm 0.04)$ & 95.6 & $0.89( \pm 0.12)$ \\
80 & 89.9 & $0.90( \pm 0.08)$ & 86.3 & $0.88( \pm 0.14)$ \\
160 & 83.4 & $0.83( \pm 0.17)$ & 77.2 & $0.80( \pm 0.15)$ \\
320 & 87.5 & $0.87( \pm 0.10)$ & $53.7 *$ & $0.72( \pm 0.14)$ \\
640 & 109.8 & $1.09( \pm 0.07)$ & $0.50( \pm 0.29)^{*}$ \\
\hline
\end{tabular}

$* \mathrm{P}<0.05$ related to control (Kruskal-Wallis test). Mean of 3 experiments. $\mathrm{SD}=$ standard deviation.

MN tests showed an increase in the frequency of micronuclei (Figure 1) induced by iron sulfate. Mean frequencies of MN per 1000 binucleated cells were 63, 68.7, and 87.3 for 40,160 , and $640 \mu \mathrm{g} / \mathrm{mL}$, respectively. Statistical significance $(\mathrm{P}<0.05)$ was observed at $640 \mu \mathrm{g} / \mathrm{mL}$ versus the negative control $(87.3 \mathrm{MN} / 1000$ versus $32 \mathrm{MN} / 1000$ binucleated cells, respectively). Cells treated with doxorubicin had a mean frequency of 148.3 MN/1000 binucleated cells, which was also statistically significant $(\mathrm{P}<0.05)$ when compared to the negative control. CBPI mean frequencies did not significantly differ between negative control and treated groups (Figure 2).

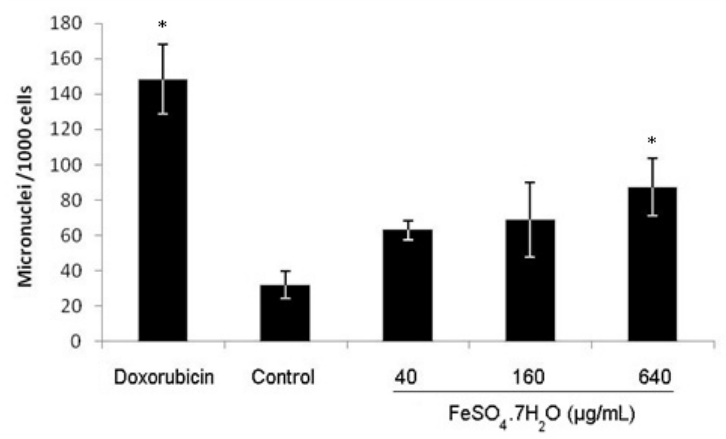

Figure 1. Micronucleus frequency observed in the U343 cell line after exposition to different concentrations of $\mathrm{FeSO}_{4} .7 \mathrm{H}_{2} \mathrm{O}$ for $24 \mathrm{~h} . * \mathrm{P}<0.05$ related to control (ANOVA). Mean of 3 experiments.

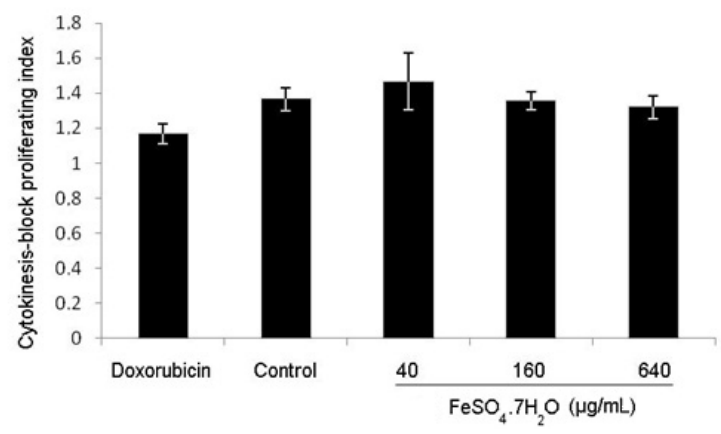

Figure 2. Cytokinesis-block proliferating index (CBPI) observed in the U343 cell line after exposition to different concentrations of $\mathrm{FeSO}_{4} \cdot 7 \mathrm{H}_{2} \mathrm{O}$ for $24 \mathrm{~h}$. ANOVA. Mean of 3 experiments. 


\section{DISCUSSION}

There is a clear relationship between a higher incidence of neurodegenerative diseases and exposure to metals. This relationship is observed in industrialized countries, where the prevalence of $\mathrm{PD}$ and $\mathrm{AD}$ is high. Prolonged exposure to $\mathrm{Al}, \mathrm{Fe}$, manganese, and other metals is, therefore, a risk factor for neurodegenerative processes (Veldman et al., 1998; Ferrer, 2003). Despite this association, few studies have assessed the cytotoxic and genotoxic effects of iron in CNS cells. This study evaluated the in vitro cytotoxic/genotoxic effects of iron in a human astrocytoma cell line (U343 MG-a). Our hypothesis was that Fe, due to its oxidative properties, induces cytotoxicity and genotoxicity in CNS cells, contributing to the development of neurodegenerative disorders and neoplasias. Normal CNS cells are very difficult to obtain; thus, we choose to use an established astrocytic cell line as a model.

Under our experimental conditions, Fe was unable to induce short-term cytotoxicity after $24 \mathrm{~h}$. However, a long-term cytotoxic effect (cell survival in the XTT assay) was observed after $96 \mathrm{~h}$. Such findings are consistent with previous reports. Lange et al. (2008) observed that an $\mathrm{Fe}$ (III)-salen organometallic compound had a cytotoxic effect in cell lines of ovarian adenocarcinoma (SKOV-3) at concentrations ranging from $100 \mathrm{nM}$ to $1 \mu \mathrm{M}$. These authors also showed that Fe(III)-salen induces apoptosis. Another research group (Woldemariam and Mandal, 2008) demonstrated that Fe(III)-salen induces cytotoxicity in HEK293 cells and induces apoptosis through a mitochondrial pathway. Chow et al. (2008) reported that ferric protoporphyrin (a toxic and highly diffusible compound released from hemoglobin was cytotoxic in C6 glioma cells. Using electrophoresis and caspase detection, they observed that this effect was due to apoptosis. Even though we did not assess cell death, it is tempting to assume that the cytotoxicity observed in this study was due to apoptotic induction combined with a possible cytostatic effect.

This study showed that iron sulfate induces micronuclei in U343 MG-a cells. Consistent with these results, Prá et al. (2008) noted that ferrous sulfate induces DNA damage in peripheral blood cells and mouse bone marrow through an increase in the frequency of micronuclei. Clastogenic effects were also induced by ferrous sulfate in a micronucleus assay (Premkumar and Bowlus, 2003) in mouse bone marrow cells. The authors reported that treatment with ascorbic acid reduced the clastogenic effect of iron, probably due to its antioxidant properties. Iron can cause significant oxidative damage, inducing mutagenesis (Pierre and Fontecave, 1999). It is likely that the clastogenic effect observed in our MN induction experiments is due to iron induction of oxidative DNA damage.

Despite the observed cytotoxic and mutagenic effects, iron sulfate did not induce changes in cell cycle kinetics, as the CBPI results were not statistically significant. However, the cytostatic effect of iron compounds was observed by others using more accurate techniques. Lange et al. (2008) observed that Fe(III)-salen delayed cell cycle progression in SKOV-3 cells. The cell cycle was evaluated by flow cytometry and the iron effect was characterized by a significant increase of S-phase cells. In another interesting study, Carlini et al. (2006) showed that iron sucrose (Fe-S) exerts a significant cytotoxic effect in bovine aortic endothelial cells. The authors stated that the effect was due to apoptosis induction and cell cycle arrest. Using immunoblot techniques, the study showed that $\mathrm{Fe}-\mathrm{S}$ induces expression of p53 and p21, widely known CDK inhibitors that block the cell cycle at the G1/S checkpoint.

The cell line used in the present study has a neoplastic origin; therefore, we must be 
cautious in our interpretation. Nevertheless, the global portrait provided by our experiments shows that iron sulfate induces cytotoxic and genotoxic alterations in U343 MG-a cells. The significant cytotoxicity might be due to the intrinsic ability of iron to induce apoptosis along with changes in cell cycle kinetics, while the iron genotoxic effects are probably due to its oxidant properties. However, other studies should be performed to better characterize this metal genotoxic action, since it remains controversial.

\section{ACKNOWLEDGMENTS}

D.D.F.A. Alcântara and H.F. Ribeiro were sponsored by Master's fellowships from CAPES. L.A. Matos and J.M.C. Sousa were sponsored by CNPq Master's fellowships.

\section{REFERENCES}

Abalea V, Cillard J, Dubos MP, Sergent O, et al. (1999). Repair of iron-induced DNA oxidation by the flavonoid myricetin in primary rat hepatocyte cultures. Free Radic. Biol. Med. 26: 1457-1466.

Alexandrov PN, Zhao Y, Pogue AI, Tarr MA, et al. (2005). Synergistic effects of iron and aluminum on stress-related gene expression in primary human neural cells. J. Alzheimers Dis. 8: 117-127.

Anderson D, Yardley-Jones A, Hambly RJ, Vives-Bauza C, et al. (2000a). Effects of iron salts and haemosiderin from a thalassaemia patient on oxygen radical damage as measured in the comet assay. Teratog. Carcinog. Mutagen. 20: 11-26.

Anderson D, Yardley-Jones A, Vives-Bauza C, Chua-Anusorn W, et al. (2000b). Effect of iron salts, haemosiderins, and chelating agents on the lymphocytes of a thalassaemia patient without chelation therapy as measured in the comet assay. Teratog. Carcinog. Mutagen. 20: 251-264.

Ayres M, Ayres JR, Ayres M and Santos AS (2007). Bioestat 5.0. Sociedade Civil Mamirauá, Belém.

Carlini RG, Alonzo E, Bellorin-Font E and Weisinger JR (2006). Apoptotic stress pathway activation mediated by iron on endothelial cells in vitro. Nephrol. Dial. Transplant. 21: 3055-3061.

Chau N, Benamghar L, Pham QT, Teculescu D, et al. (1993). Mortality of iron miners in Lorraine (France): relations between lung function and respiratory symptoms and subsequent mortality. Br. J. Ind. Med. 50: 1017-1031.

Chow JM, Huang GC, Lin HY, Shen SC, et al. (2008). Cytotoxic effects of metal protoporphyrins in glioblastoma cells: roles of albumin, reactive oxygen species, and heme oxygenase-1. Toxicol. Lett. 177: 97-107.

Dunkel VC, San RH, Seifried HE and Whittaker P (1999). Genotoxicity of iron compounds in Salmonella typhimurium and L5178Y mouse lymphoma cells. Environ. Mol. Mutagen. 33: 28-41.

Fasano M, Giraudo S, Coha S, Bergamasco B, et al. (2003). Residual substantia nigra neuromelanin in Parkinson's disease is cross-linked to alpha-synuclein. Neurochem. Int. 42: 603-606.

Fenech M, Chang WP, Kirsch-Volders M, Holland N, et al. (2003). HUMN project: detailed description of the scoring criteria for the cytokinesis-block micronucleus assay using isolated human lymphocyte cultures. Mutat. Res. 534: $65-75$.

Ferrer A (2003). Metal poisoning. An. Sist. Sanit. Navar. 26 (Suppl 1): 141-153.

Gardi C, Arezzini B, Fortino V and Comporti M (2002). Effect of free iron on collagen synthesis, cell proliferation and MMP-2 expression in rat hepatic stellate cells. Biochem. Pharmacol. 64: 1139-1145.

Heidelberger C, Freeman AE, Pienta RJ, Sivak A, et al. (1983). Cell transformation by chemical agents - a review and analysis of the literature. A report of the U.S. Environmental Protection Agency Gene-Tox Program. Mutat. Res. 114: $283-385$.

Hiyama H and Reeves SA (1999). Role for cyclin D1 in UVC-induced and p53-mediated apoptosis. Cell Death Differ. 6: $565-569$.

Lange TS, Kim KK, Singh RK, Strongin RM, et al. (2008). Iron(III)-salophene: an organometallic compound with selective cytotoxic and anti-proliferative properties in platinum-resistant ovarian cancer cells. PLoS One 3: e2303.

Linehan WM, Srinivasan R and Schmidt LS (2010). The genetic basis of kidney cancer: a metabolic disease. Nat. Rev. Urol. 7: 277-285.

Lukiw WJ and Pogue AI (2007). Induction of specific micro RNA (miRNA) species by ROS-generating metal sulfates in primary human brain cells. J. Inorg. Biochem. 101: 1265-1269. 
O’Neil P (1994). Major Elements in the Earth's Crust - Iron. In: Environmental Chemistry. 2nd ed. Chapman and Hall, New York, 151-168.

Pierre JL and Fontecave M (1999). Iron and activated oxygen species in biology: the basic chemistry. Biometals 12: 195199.

Prá D, Franke SI, Giulian R, Yoneama ML, et al. (2008). Genotoxicity and mutagenicity of iron and copper in mice. Biometals 21: 289-297.

Premkumar K and Bowlus CL (2003). Ascorbic acid reduces the frequency of iron induced micronuclei in bone marrow cells of mice. Mutat. Res. 542: 99-103.

Rivera-Mancía S, Pérez-Neri I, Rios C, Tristán-López L, et al. (2010). The transition metals copper and iron in neurodegenerative diseases. Chem. Biol. Interact. 186: 184-199.

Salonen JT, Nyyssonen K, Korpela H, Tuomilehto J, et al. (1992). High stored iron levels are associated with excess risk of myocardial infarction in eastern Finnish men. Circulation 86: 803-811.

Smith MA, Harris PL, Sayre LM and Perry G (1997). Iron accumulation in Alzheimer disease is a source of redoxgenerated free radicals. Proc. Natl. Acad. Sci. U. S. A. 94: 9866-9868.

Trinder D, Fox C, Vautier G and Olynyk JK (2002). Molecular pathogenesis of iron overload. Gut 51: 290-295.

Veldman BA, Wijn AM, Knoers N, Praamstra P, et al. (1998). Genetic and environmental risk factors in Parkinson's disease. Clin. Neurol. Neurosurg. 100: 15-26.

Woldemariam GA and Mandal SS (2008). Iron(III)-salen damages DNA and induces apoptosis in human cell via mitochondrial pathway. J. Inorg. Biochem. 102: 740-747. 